\title{
The anomuran and brachyuran communities (Crustacea: Decapoda) in sheltered and exposed rocky shores from Anchieta and Guarapari regions (Espírito Santo), Brazil
}

\author{
Crislene Cristo Ribeiro ${ }^{1,4}$, Adriane Araújo Braga ${ }^{2,4}$, Erika Takagi Nunes ${ }^{2}$ \\ Ana Paula Madureira ${ }^{3}$ \& Giovana Bertini ${ }^{4}$ \\ ${ }^{1}$ São Paulo State University (UNESP), Campus of Registro, Registro, SP, Brazil \\ ${ }^{2}$ Department of Biology, Center of Exact Natural and Health Sciences \\ Federal University of Espírito Santo, Alegre, ES, Brazil \\ ${ }^{3}$ Department of Biosystems Engineering São João Del Rei \\ Federal University of São João Del Rei, MG, Brazil \\ ${ }^{4}$ Laboratory of Biology and Culture of Crustaceans (LABCRUST) \\ São Paulo State University (UNESP), São Paulo, Brazil \\ Corresponding author: Crislene Cristo Ribeiro (crislenebio@yahoo.com.br)
}

\begin{abstract}
Rocky shores are ecosystems susceptible to anthropic impact, and the absence of information in Brazil about their biota hampers characterization and conservation measures. Thus, this study analyzed the abundance, richness, diversity and dominance of anomuran and brachyuran communities in sheltered and exposed rocky shores in Anchieta and Guarapari on the coast of Espírito Santo State. It was also studied the community variation concerning the types of rocky shores during the rainy and dry seasons. The organisms were collected manually in the mediolittoral zone of the rocky shores from October 2014 to September 2015. Additionally, temperature and salinity of the water were measured and the rainfall recorded from a meteorological station. In this study, 3,156 individuals were collected, comprising 14 species. The hermit crabs Clibanarius antillensis and Calcinus tibicen were the most abundant species. The three-way ANOVA analysis revealed that there was no interaction between ecological indices and the study locations, rocky shores and seasons. The abundance of the decapod community was statistically different between locations. The richness and diversity indices were higher on the sheltered rocky shore because of the presence of rock fragments and heterogeneous sediments, they are providing higher availability of microhabitats in these areas. There was no relationship between the decapod community and environmental factors, possibly because of a small variation of these factors registered between rainy and dry seasons. It is concluded that the anomuran and brachyuran communities are probably more influenced by biological interactions and physiographic features of rocky shores than by environmental factors.
\end{abstract}

Keywords: mediolittoral zone; abundance; richness; diversity; decapods

\section{INTRODUCTION}

Rocky shores are highly heterogeneous environments typically formed by rocks of varying sizes, steep walls, flat areas and tidal pools (Ghilardi et al., 2008). This heterogeneity is one of the main factors influencing the distribution and abundance of biotic communities living in these areas (Araújo et al., 2005; Ahmad et al., 2011).
Several species found in rocky shores are often unique to this ecosystem, since these organisms must be able to withstand numerous physical factors, such as luminosity, salinity variation, temperature, wave hydrodynamics, topography and substrate type (Ghilardi et al., 2008; Moreno \& Rocha, 2012; Coutinho et al., 2016). In addition, they are also subjected to biological factors, especially predation and competition (Wilson, 1991; Moreno \& Rocha, 2012).

Corresponding editor: Ingo Wehrtmann 
Macroinvertebrates $(>0.5 \mathrm{~cm})$ are considered the most abundant and diverse organisms found on the rocky shores (Abushaala et al., 2014). Crustacean decapods are an essential part of this fauna, and are fundamental to the maintenance and balance of this ecosystem since they contribute to the recycling of nutrients and organic matter, besides of serving as food for other organisms such as fish and birds, and, in some cases also for humans (Fransozo et al., 2011; Abushaala et al., 2014).

Information related to the species composition, richness, abundance and distribution patterns provides an important tool for understanding the functioning of the coastal ecosystems (Bertini et al., 2004; Nanami et $a l ., 2005)$. Knowledge of species composition and abundance is a fundamental parameter for comparing communities under the influence of natural and anthropogenic disturbances (Olawusi-Peters \& Ajibare, 2014). In this sense, studies focusing on rocky coastal ecosystems are important since they are susceptible to anthropic impacts (Crowe et al., 2000; Thompson et al., 2002). The detection of impacts and the possible consequences on the environment, however, are often hampered by an absence of basic information on the species inhabiting these sites, preventing the implementation of measures for their conservation and restoration (Ghilardi et al., 2008; Pohle et al., 2011).

The coast of Espírito Santo (ES), southeastern Brazil, has been subjected to several anthropic activities, such as fishing and shellfishing, recreation, tourism, urbanization, mining and industrial and port activities. All of these activities may change the biota of coastal environments. Barbosa et al. (2008) suggested tourism as the main impact factor for the algal communities of the mediolittoral zone in Jacaraípe Beach (ES), and Zalmon et al. (2011) found low macrofaunal richness in sites exposed to high influence of domestic sewage in the Vitória Harbor (ES).

Some of the studies conducted on the rocky shores of Espírito Santo State are related to floristic surveys (Nalesso et al., 2005), fish communities (Floeter et al., 2007; Macieira \& Joyeux, 2011), overall macrofauna (Ramos et al., 2010; Zamprogno et al., 2012; Cruz, 2014) and mollusks (Silva \& Castro, 2014). Coutinho et al. (2016), in a review study on the benthic community of the rocky coasts of Brazil, mentioned that among the states of the southeast, ES had the fewest published studies related to the rocky shores' benthic community. Thus, studies involving the characterization, composition and distribution of decapod crustaceans are practically non-existent, although it is well known that they are common inhabitants of this ecosystem.
Therefore, the present study aimed to analyze the structure of the anomuran and brachyuran community present in sheltered and exposed rocky shores of the municipalities of Anchieta and Guarapari, both in the coast of ES State, Brazil, with two distinct physiographic features. The study focused on abundance, species richness, diversity, dominance, as well as on the community variation relative to the types of rocky shores during rainy and dry seasons.

\section{MATERIALS AND METHODS}

\section{Data collection}

This study was carried out in two municipalities of ES, Brazil: Costa Azul Beach, located in the Balneary of Iriri, Anchieta, southern region of the state and Ermitão Beach in Morro da Pescaria Municipal Park, Guarapari, in the metropolitan region of ES (Fig. 1).

At both beaches, two rocky shores with distinct physiographic features based on the Széchy \& Paula (2000) methodology were identified for the collection of decapods: a) sheltered rocky coast - characterized by low hydrodynamics with little wave action on the slopes. In both locations, it was a rocky-sandy beach made up of rock fragments of various sizes, entirely exposed at low tide. The presence of sand reefs, algal and bivalve banks and corals was rare, b) exposed rocky coast - characterized by a steep rocky shore and high hydrodynamism with strong wave on the slopes and continuous walls. These locations were entirely exposed at low tide with large tidal pools occupied by algae and invertebrates such as crustaceans, sea urchins, sea anemones, mollusks and corals.

Bi-monthly collections were carried out from October 2014 through September 2015 with three collections in the rainy season (October to March) and three in the dry season (April to September). The determination of the rainy and dry seasons of the state of ES was based on Ramos et al. (2016).

The collection effort was defined in pilot collections, and sampling efforts with two persons during $20 \mathrm{~min}$ and another one with one person for 10 min were tested. We noticed that the number of hermit crabs increased considerably in the 20 min collection, mainly in Guarapari, known as hermit crab beach. Thus, to avoid impacting the hermit crab population, the sampling was standardized as a one-person collection for 10 min during low tide in two areas of the mediolittoral zone approximately $15 \mathrm{~m}$ apart. A manual sampling at the sheltered rocky shore was performed on the sediment and through rock displacement to uncover decapods present since, in this environment, there was no other type of biogenic substrate. In the exposed 


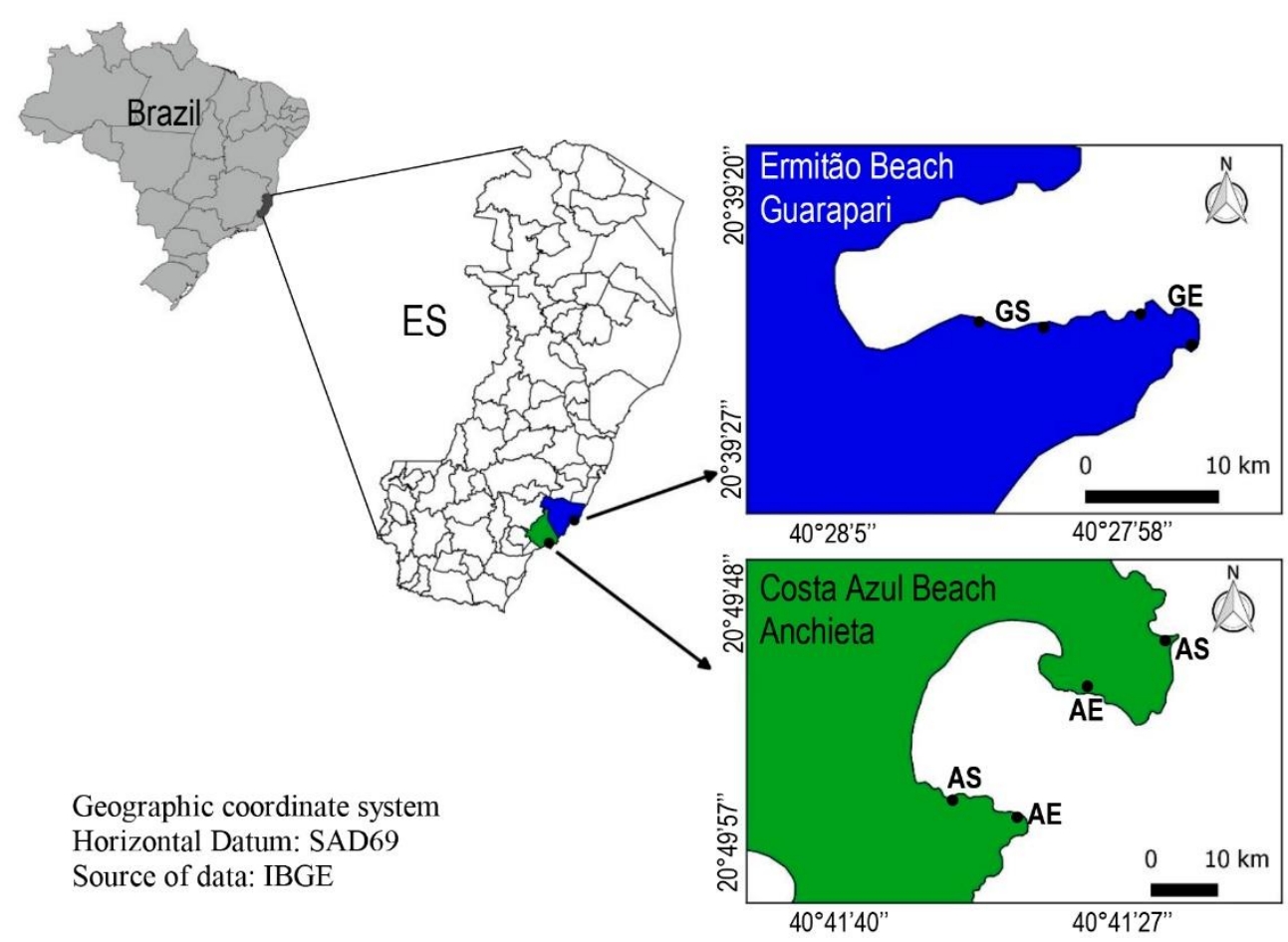

Figure 1. Map of Espírito Santo indicating the two municipalities with the sampling areas: Costa Azul Beach (Anchieta) and Ermitão Beach (Guarapari), Brazil. The dots indicate sheltered (AS, GS) and exposed (AE, GE) the rocky shores sampled at each beach.

rocky coast the collections were carried out inside the tidal pools.

Water temperature and salinity were measured at each site using a mercury column thermometer and a specific optical refractometer, respectively. At the sheltered rocky shore, the water was collected on the sea surface and inside the tidal pool at the exposed rocky shore. Rainfall data covering the week before each sampling until the day of the collection were obtained from the Instituto Capixaba de Pesquisa, Assistência Técnica e Extensão Rural (INCAPER). The collected decapods were bagged, labeled and stored in a styrofoam box containing ice, and transported to the Zoology Laboratory in Alegre-ES where they were kept frozen until analysis.

The decapods were identified according to the literature (Melo, 1996, 1999), and the taxonomic classification was based on that of De Grave et al. (2009). After the analyses, all specimens or a sample of 10 individuals of each species were stored in vials containing $70 \%$ alcohol and deposited in the scientific collection of the Universidade Federal do Espírito Santo, Alegre.

\section{Data analysis}

Before applying the ANOVA tests, the data were checked for normality (Kolmogorov-Smirnov) and homogeneity (Levene test). In the absence of homogeneity, data were log-transformed before the ANOVA test; results were considered significant when $P<0.05$. Small deviations from normality or homogeneity after transformation were accepted because ANOVA is considered to be robust to such violations (Zar, 1999). A two-way ANOVA was used to evaluate the differences of environmental factors (water temperature, salinity and rainfall) between regions and seasons.

The decapod community was analyzed in relation to the type of rocky shore (sheltered and exposed) and to the sampling location (Anchieta and Guarapari), being AS (Anchieta: rocky shore sheltered), AE (Anchieta: rocky shore exposed), GS (Guarapari: rocky shore sheltered) and GE (Guarapari: rocky shore exposed). The two sampled areas in each rocky shore were considered as replicates, totalizing six samples in AS, $\mathrm{AE}, \mathrm{GS}$ and GE in each season.

The following ecological indices were calculated: 1 ) species richness as the number of species obtained in a sampling unit (Krebs, 1998), 2) species diversity by using the Shannon-Weaver index $\left(\mathrm{H}^{\prime}: \log _{2}\right.$; bits ind $\left.{ }^{-1}\right)$, 3) equitability index $\left(J^{\prime}\right)$ by Pielou (1966), and 4) dominance index: $\mathrm{dN}_{\max } / \mathrm{N}$, where $N_{\max }$ is the number of individuals in the most abundant species (Berger \& Parker, 1970). 
The total abundance, richness of species $(S)$, species diversity $\left(H^{\prime}\right)$, equitability $\left(J^{\prime}\right)$ and dominance index $(d)$ were contrasted using a three-way factorial ANOVA to test the null hypothesis of no differences in ecological indices associated with the factors "regions", "rocky shores" and "seasons".

Rarefaction curves were constructed for each rocky shore (sheltered and exposed) to compare taxonomical diversity in samples of different sizes. For this calculation, species absolute abundance data were used to estimate the number of taxa that would be expected in a sample with a few individuals. The algorithm described by Krebs (1998) was adopted for this analysis. The standard errors were converted to $95 \%$ confidence intervals in the graphical plot (Colwell et al., 2004).

The frequency of species occurrence (\%) was calculated by the percentage of occurrence of a species in relation to the total number of collections in each type of rocky shore (12), calculated as: $\mathrm{Fa}=(\mathrm{Pa} / \mathrm{P}) \times$ 100, where: $F a$ is species frequency, $P a$ number of collections in which the species was present and $P$ total number of collections (48). According to the results, the species were classified as: constant $(75 \%<\mathrm{Fa} \leq 100 \%)$; very common $(50 \%<\mathrm{Fa} \leq 75 \%)$; common $(25 \%<\mathrm{Fa}$ $\leq 50 \%)$; occasional $(10 \%<\mathrm{Fa} \leq 25 \%)$, and rare $(\leq 10 \%)$ (Dajoz, 2005; Odum \& Barrett, 2007).

Correspondence analyses (CA) were used to evaluate the relationship between the abundance of decapods and types of rocky shores. In these analyses, absolute abundance was used, considering each species as a group of independent data, minimizing the influence of sampling design (Leps \& Smilauer, 2003). The data were ordered by canonical correlation analysis (CCA) (Gittins, 1985) to reveal possible patterns among environmental factors and decapods abundance.

Prior to multivariate analysis (CA and CCA), the data were simplified by eliminating species with a frequency less than or equal to 25\% (Bertini et al., 2010; Barros-Alves et al., 2017).

\section{RESULTS}

\section{Environmental factors}

The average surface water temperature was statistically different between the regions $(\mathrm{F}=5.76, P=0.021)$ : Anchieta showed a higher mean temperature $(25.2 \pm$ $\left.1.9^{\circ} \mathrm{C}\right)$ compared to Guarapari $\left(23.9 \pm 1.7^{\circ} \mathrm{C}\right)$. No statistical difference $(\mathrm{F}=0.46, P=0.503)$ was detected between dry and rainy seasons. There was, however, an interaction between regions and season, showing that the temperature in the rainy season in Anchieta (25.9 \pm $\left.1.9^{\circ} \mathrm{C}\right)$ was significantly higher than in Guarapari $(23.5$ $\pm 1.9^{\circ} \mathrm{C}$ ) (Fig. 2).

For environmental salinity factor, no statistical difference between regions and seasons was detected $(P$ $>0.05)$. The mean water salinity in the rainy and dry season in Anchieta was $37.1 \pm 2.5$ and $35.7 \pm 2.9$, respectively, while in Guarapari the average salinity in the rainy season was $37.5 \pm 2.5$ and $36.7 \pm 0.8$ in the dry season (Fig. 2).

Rainfall recorded in the Anchieta and Guarapari regions during the study period was atypical for the region, with a low rainfall index during the rainy season. A two-way ANOVA detected a statistical difference between regions and seasons, but there was no interaction between the factors. Guarapari showed higher average rainfall $(3.69 \pm 2.91 \mathrm{~mm})$ in the week prior to collection compared to Anchieta $(2.31 \pm 2.53$ $\mathrm{mm})(\mathrm{F}=4.34 ; P=0.04)$. In the dry season $(4.53 \pm 3.02$ $\mathrm{mm}$ ) in Anchieta, it rained more in the week before the collection than in the rainy season $(1.46 \pm 1.34 \mathrm{~mm})(\mathrm{F}$ $=21.78 ; P=0.000$ ) (Fig. 2).

\section{Community structure}

A total of 3,156 anomuran and brachyuran individuals was collected, comprising 14 decapod species (7 Anomura and 7 Brachyura); 11 species were collected in both regions. The Guarapari region had the highest abundance with 2,134 individuals, and Anchieta was represented by 1,022 individuals (Table 1 ).

Among the Anomura, the family Diogenidae had the highest number of species (four), followed by Paguridae (two) and Porcellanidae (one). The Brachyura was represented by families Epialtidae, Eriphiidae, Grapsidae, Majidae and Menippidae with one species each and by Panopeidae family with two species (Table 1).

Anomura was represented by 2,946 specimens, with Clibanarius antillensis being the most abundant species $(\mathrm{n}=1,766)$ followed by Calcinus tibicen $(\mathrm{n}=1,029)$. A total of 210 individuals of brachyuran crabs was collected, with Eurypanopeus abbreviatus being the most abundant crab $(\mathrm{n}=115)$ (Table 1). Most decapod species collected in Guarapari and Anchieta were present in both seasons (Table 2).

The average values of abundance, species richness, diversity, equitability, and the dominance indices at the Anchieta and Guarapari rocky shores are shown in Figure 3. The three-way factorial ANOVA revealed that ecological indices did not show an interaction with the factors "regions", "rocky shores", and "seasons" (Table 3). Significant differences, however, were observed between regions concerning abundance, with statistically higher values in Guarapari (88.92 ind) than 

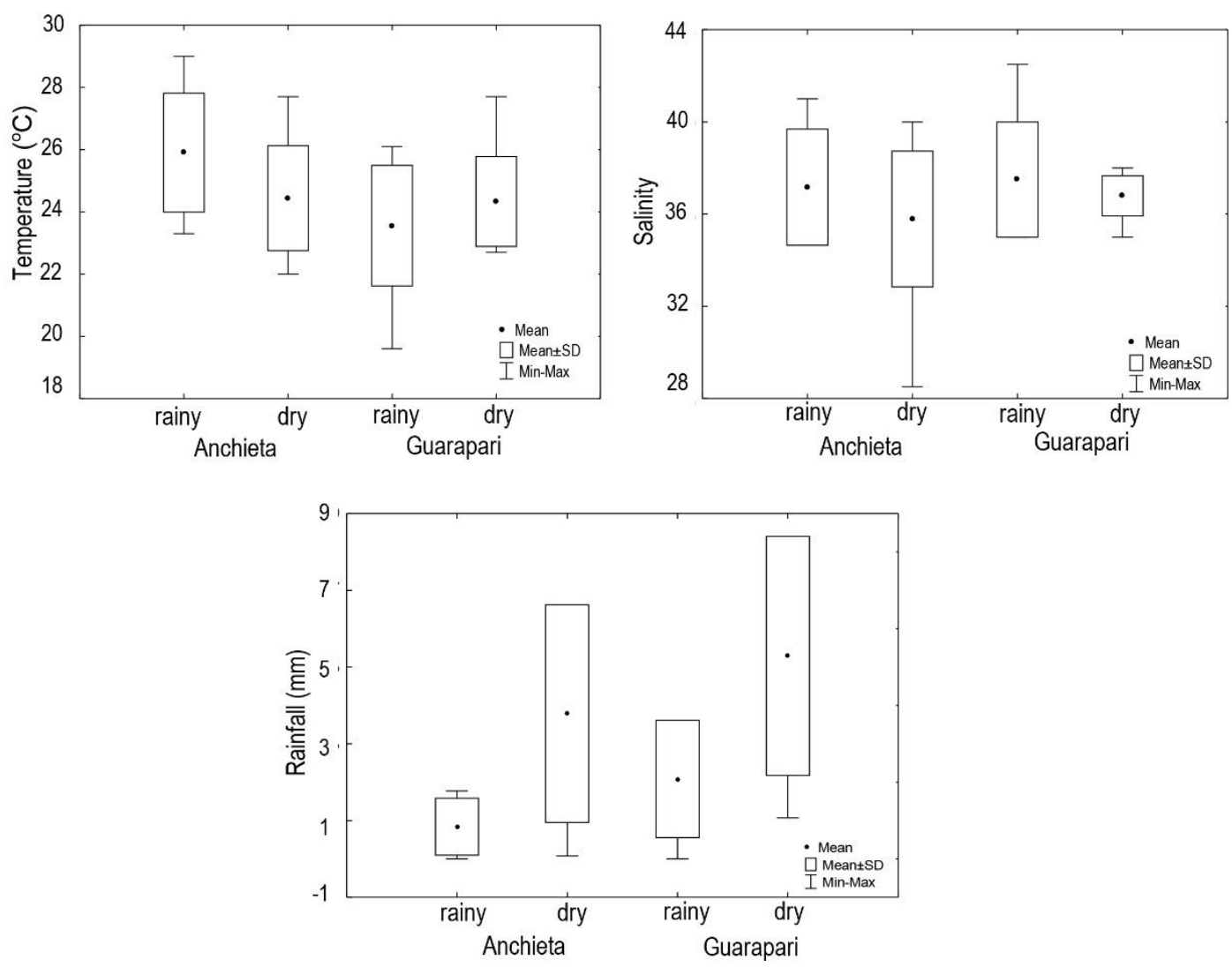

Figure 2. Box plot of the temperature, salinity and rainfall during the seasons (rainy and dry) in Anchieta and Guarapari, Espírito Santo, southeastern Brazil.

in Anchieta (42.58 ind). The species richness $(S)$ and the diversity $\left(H^{\prime}\right)$ showed significant differences between the "rocky shores" factor, where sheltered rocky shores showed the higher richness $(S=4.9)$ and diversity $\left(H^{\prime}=1.30\right)$ compared to exposed rocky shores $\left(S=3.0 ; H^{\prime}=0.78\right)$ (Table 3$)$. In addition, the diversity index was statistically higher in the Anchieta $\left(H^{\prime}=\right.$ 1.23) than in Guarapari $\left(H^{\prime}=0.85\right)$.

The rarefaction curves performed for 200 individuals showed a higher species richness in the sheltered rocky shores of both regions (Anchieta and Guarapari), indicating a tendency of stabilization of the number of species collected in the environments sampled (Fig. 4).

The relationships among the decapod's abundance and rocky shores were analyzed with the correspondence analysis (CA) (Fig. 5). The species Acantholobulus schmitti, Pachygrapsus transversus, Petrolisthes armatus, and E. abbreviatus showed high correspondence with sheltered rocky shores (AS and GS), whereas $C$. tibicen was associated mainly with GE. The species $C$. antillensis was abundant in all rocky shores, but with a high correspondence with GS and AE, whereas Pagurus brevidactylus, Pagurus criniticornis and Omalacantha antillensis showed high correspondence preferentially with AE and AS.

The canonical correlation analysis of species abundance and environmental factors revealed that there was no significant correlation $(\mathrm{R}=0.64 ; P=$ $0.07)$, suggesting that temperature, salinity and rainfall did not influence species distribution.

\section{Frequency of occurrence}

The frequency of occurrence of species differed between the rocky shores. The hermit crab $C$. antillensis was constant (>75\% of the frequency of occurrence) in all of the rocky shores sampled and $C$. tibicen was constant only in Guarapari.

At Anchieta rocky shores, the hermit crabs $P$. criniticornis and $P$. brevidactylus showed a frequency ranging from common to occasional, whereas in Guarapari these hermits ranged from occasional to rare. In the sheltered rocky shores of both regions, the frequency of $P$. armatus, E. abbreviatus, A. schmitti, and $P$. transversus varied between from common to constant. The species Menippe nodifrons, Eriphia and Epialtus bituberculatus were rare for all rocky shore (Table 1). 
Table 1. Number of individuals (n) and frequency of occurrence (FO) of decapod species in each type of rocky shore (sheltered and exposed) in Anchieta and Guarapari, Espírito Santo, southeastern Brazil. She: sheltered, Exp: exposed, ct: constant, vc: very common, cm: common, oc: occasional, ra: rare.

\begin{tabular}{|c|c|c|c|c|c|c|c|c|c|c|}
\hline \multirow{3}{*}{ Infraorder/Family/Species } & \multicolumn{5}{|c|}{ Anchieta } & \multicolumn{5}{|c|}{ Guarapari } \\
\hline & \multicolumn{2}{|c|}{ She } & \multicolumn{2}{|c|}{ Exp } & \multirow{2}{*}{$\frac{\text { Total }}{\mathrm{n}}$} & \multicolumn{2}{|c|}{ She } & \multicolumn{2}{|c|}{ Exp } & \multirow{2}{*}{$\begin{array}{c}\text { Total } \\
\mathrm{n}\end{array}$} \\
\hline & $\mathrm{n}$ & FO & $\mathrm{n}$ & $\mathrm{FO}$ & & $\mathrm{n}$ & FO & $\mathrm{n}$ & FO & \\
\hline \multicolumn{11}{|l|}{ Anomura } \\
\hline \multicolumn{11}{|l|}{ Diogenidae } \\
\hline Calcinus tibicen (Herbst, 1791) & 25 & $\mathrm{~cm}$ & 72 & $\mathrm{vc}$ & 97 & 112 & ct & 820 & ct & 932 \\
\hline Clibanarius antillensis Stimpson, 1859 & 292 & ct & 418 & $\mathrm{ct}$ & 710 & 667 & ct & 389 & ct & 1,056 \\
\hline Clibanarius sclopetarius (Herbst, 1796) & 3 & $\mathrm{oc}$ & 2 & $\mathrm{oc}$ & 5 & 0 & - & 0 & - & 0 \\
\hline Paguristes tortugae Schmitt, 1933 & 3 & $\mathrm{oc}$ & 2 & oc & 5 & 0 & - & 1 & ra & 1 \\
\hline \multicolumn{11}{|l|}{ Paguridae } \\
\hline Pagurus brevidactylus (Stimpson, 1859) & 7 & oc & 3 & $\mathrm{oc}$ & 10 & 1 & ra & 2 & ra & 3 \\
\hline Pagurus criniticornis (Dana, 1852) & 10 & $\mathrm{~cm}$ & 13 & $\mathrm{~cm}$ & 23 & 0 & - & 2 & oc & 2 \\
\hline \multicolumn{11}{|l|}{ Porcellanidae } \\
\hline Petrolisthes armatus (Gibbes, 1850) & 54 & $\mathrm{vc}$ & 1 & ra & 55 & 47 & $\mathrm{vc}$ & 0 & - & 47 \\
\hline \multicolumn{11}{|l|}{ Brachyura } \\
\hline \multicolumn{11}{|l|}{ Epialtidae } \\
\hline $\begin{array}{l}\text { Epialtus bituberculatus } \text { H. Milne Edwards, } 1834 \\
\text { Eriphiidae }\end{array}$ & 0 & - & 0 & - & 0 & 0 & - & 1 & ra & 1 \\
\hline Eriphia gonagra (Fabricius, 1781) & 1 & ra & 0 & - & 1 & 1 & ra & 0 & - & 1 \\
\hline \multicolumn{11}{|l|}{ Grapsidae } \\
\hline Pachygrapsus transversus (Gibbes, 1850) & 22 & $\mathrm{vc}$ & 0 & - & 22 & 23 & ct & 1 & ra & 24 \\
\hline Majidae & & & & & & & & & & \\
\hline Omalacantha antillensis (Rathbun, 1920) & 1 & ra & 23 & $\mathrm{~cm}$ & 24 & 1 & ra & 2 & $\mathrm{oc}$ & 3 \\
\hline \multicolumn{11}{|l|}{ Menippidae } \\
\hline Menippe nodifrons Stimpson, 1859 & 1 & ra & 0 & - & 1 & 0 & - & 0 & - & 0 \\
\hline \multicolumn{11}{|l|}{ Panopeidae } \\
\hline Acantholobulus schmitti (Rathbun, 1930) & 11 & $\mathrm{~cm}$ & 1 & ra & 12 & 6 & $\mathrm{~cm}$ & 0 & - & 6 \\
\hline Eurypanopeus abbreviates (Stimpson, 1860) & 53 & $\mathrm{vc}$ & 4 & $\mathrm{oc}$ & 57 & 58 & ct & 0 & - & 58 \\
\hline Number of individuals & 483 & & 539 & & 1,022 & 916 & & 1,218 & & 2,134 \\
\hline Species richness & 13 & & 10 & & 13 & 9 & & 8 & & 12 \\
\hline Diversity index (bits ind ${ }^{-1}$ ) & 2.04 & & 1.18 & & 1.75 & 1.39 & & 0.98 & & 1.44 \\
\hline Equitability index & 0.55 & & 0.35 & & 0.47 & 0.43 & & 0.32 & & 0.40 \\
\hline Dominance index & 0.60 & & 0.77 & & 0.69 & 0.73 & & 0.67 & & 0.49 \\
\hline
\end{tabular}

\section{DISCUSSION}

The brachyuran and anomuran species that inhabit the rocky shores of the coast of ES were studied for the first time. Such information is highly relevant for future studies about the fauna because these ecosystems can change the species composition caused by anthropic activities. Coutinho et al. (2016) emphasized the importance of surveys of benthic communities in the rocky coasts in Brazil, which can be used as a basis for future studies on the effects of environmental changes on the respective biota and may help, for example, to develop a better and more accurate prediction of climate change impacts on this environment and its biota.
The community structure of anomuran and brachyuran crabs showed differences concerning the regions (Anchieta and Guarapari) and types of rocky shores. Sheltered rocky shores, regardless of location, showed higher diversity and species richness (13 species in total), whereas species abundance was significantly higher in Guarapari.

Differences in faunal composition among coastal marine ecosystems have been reported in the literature, and are related to the adaptation of the species to each type of environment, with more complex environments providing more refuge for invertebrate survival from predators and environmental stress (Bruno \& Bertness, 2001; Nucci et al., 2001; Araújo et al., 2005; Zamprogno et al., 2012; Abushaala et al., 2014; Morais \& Lee, 2014; Barros-Alves et al., 2017). Thus, species 
Table 2. Number of individuals of decapod species for rainy and dry seasons in Anchieta and Guarapari, Espírito Santo, southeastern Brazil.

\begin{tabular}{|c|c|c|c|c|c|c|}
\hline \multirow{2}{*}{ Infraorder/Family/Species } & \multicolumn{3}{|c|}{ Anchieta } & \multicolumn{3}{|c|}{ Guarapari } \\
\hline & Rainy & Dry & Total & Rainy & Dry & Total \\
\hline \multicolumn{7}{|l|}{ Anomura } \\
\hline \multicolumn{7}{|l|}{ Diogenidae } \\
\hline Calcinus tibicen & 54 & 43 & 97 & 445 & 487 & 932 \\
\hline Clibanarius antillensis & 360 & 350 & 710 & 493 & 563 & 1056 \\
\hline Clibanarius sclopetarius & 2 & 3 & 5 & 0 & 0 & 0 \\
\hline Paguristes tortugae & 2 & 3 & 5 & 0 & 1 & 1 \\
\hline $\begin{array}{l}\text { Paguridae } \\
\text { Pagurus brevidactvlus }\end{array}$ & 4 & 6 & 10 & 0 & 3 & 3 \\
\hline Pagurus criniticornis & 7 & 16 & 23 & 1 & 1 & 2 \\
\hline \multicolumn{7}{|l|}{ Porcellanidae } \\
\hline Petrolisthes armatus & 41 & 14 & 55 & 24 & 23 & 47 \\
\hline \multicolumn{7}{|l|}{ Brachyura } \\
\hline Epialtidae & & & & & & \\
\hline $\begin{array}{l}\text { Epialtus bituberculatus } \\
\text { Eriphiidae }\end{array}$ & 0 & 0 & 0 & 1 & 0 & 1 \\
\hline $\begin{array}{l}\text { Eriphia gonagra } \\
\text { Grapsidae }\end{array}$ & 1 & 0 & 1 & 0 & 1 & 1 \\
\hline $\begin{array}{l}\text { Pachygrapsus transversus } \\
\text { Majidae }\end{array}$ & 6 & 16 & 22 & 16 & 8 & 24 \\
\hline $\begin{array}{l}\text { Omalacantha antillensis } \\
\text { Menippidae }\end{array}$ & 6 & 18 & 24 & 2 & 1 & 3 \\
\hline Menippe nodifrons & 1 & 0 & 1 & 0 & 0 & 0 \\
\hline Panopeidae & & & & & & \\
\hline Acantholobulus schmitti & 11 & 1 & 12 & 3 & 3 & 6 \\
\hline Eurypanopeus abbreviatus & 45 & 12 & 57 & 38 & 20 & 58 \\
\hline Number of individuals & 540 & 482 & 1022 & 1023 & 1111 & 2134 \\
\hline Species richness & 13 & 11 & 13 & 9 & 11 & 12 \\
\hline
\end{tabular}

richness and abundance may increase in habitats with increased complexity or roughness (Kawasaki et al., 2003). Therefore, the higher diversity and species richness of anomurans and brachyurans obtained in the sheltered coastlines of both regions are possibly related to the lower impact of the waves and the formation of complex microhabitats, composed of fragments of rocks of varied sizes and heterogeneous sediment, providing favorable conditions for the presence of many species.

A higher diversity of decapod species has also been observed in coastal reef environments with low hydrodynamics on the coast of Pernambuco (Brazil) by Giraldes et al. (2012). These results were related to the association of individuals in substrate formed by algae, sponges and corals, whereas the open areas of the reefs with higher exposure to the wave action presented lower diversity, displaying few species adapted to live only in caves and cracks of the corals where they protect themselves from the action of the waves.

According to Flores \& Paula (2001), within a single marine habitat, such as rocky shores, the number of substrates available for the decapod crustaceans is usually variable, and differences in diversity may depend more on the area where each substrate occurs. Therefore, the diversity of species in each ecosystem may differ according to the environment available in each region, as observed in the present study, and by Masunari \& Dubiaski-Silva (1998) who registered 17 species of anomurans and brachyurans in Ilha do Farol (PR), southern Brazil, of which four were frequent in the present study. Other studies have focused only on brachyurans: Nóbrega \& Martinelli-Lemos (2016) found 14 species of crabs in a rocky substrate at an estuary of the Brazilian Amazonian coast. Leite et al. (1998), on the other hand, focused on anomurans and found nine hermit crab species in the rocky shores of the São Sebastião Channel, northern coast of the state of São Paulo.

The diversity and richness of species of Anomura and Brachyura found in the present study can be considered high when compared to the study of Giraldes et al. (2012) at the coastal reef of Porto de Galinhas Beach, northeastern Brazil. In addition, the results of the rarefaction curves (Fig. 4) obtained for the sheltered and exposed shores of both locations, indicated a stabilization tendency of the species number, which suggests that the species number obtained is close to the accurate richness of the region, and that the sampling effort was adequate for the decapod species inhabiting these rocky shores (Schilling \& Bastista, 2008; Gotelli \& Colwell, 2010).

The high number of decapods in Guarapari is related to the presence of two species of hermit crabs (Clibanarius antillensis and Calcinus tibicen). C. antillensis was the most abundant species in this study and showed a frequency of occurrence above $75 \%$ (constant) in all rocky shores, but particularly in GS. According to Osawa \& Fujita (2008), species of the genus Clibanarius are frequent inhabitants of shallow waters and intertidal zones, where they inhabit rocky shores, coral reefs and estuarine areas, and they show high resistance to environmental variations. Moreover, to inhabit the intertidal regions, the hermit crabs must have physiological and behavioral adaptations to deal with water loss (Bertness, 1981; Taylor, 1981; Gherardi \& Vannini, 1993). Therefore, in all the field collections, C. antillensis showed a grouping behavior and was able to occupy cracks during periods of low tide to reduce water loss (see also Leite et al., 1998).

The second most abundant species was the hermit crab C. tibicen, found in the exposed coast of Guarapari and frequently collected inside tidal pools, which coincides with similar observations made by Almeida et al. (2010) in the south of Bahia. Conversely, Leite et al. (1998) collected C. tibicen mainly in the sublittoral zone and rarely in the tidal pools of the northern coast of the state of São Paulo.

The high frequency of these hermit crabs $(C$. antillensis and $C$. tibicen) in Guarapari may be related to the availability of gastropod shells in this environ- 

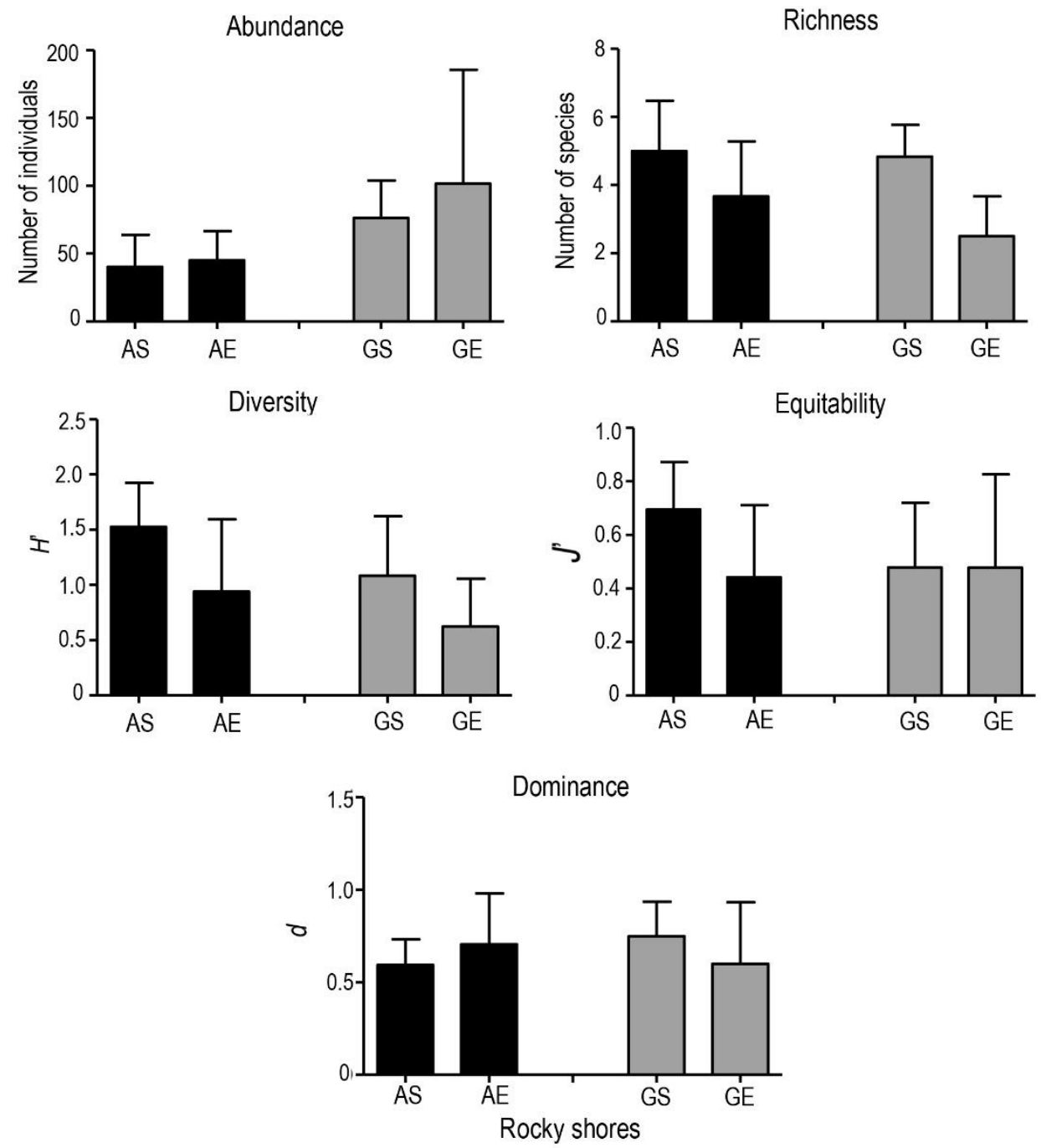

Figure 3. Mean values and standard deviations of decapod abundance, species richness, diversity, equitability and dominance indices for each rocky shore studied in southeastern Brazil. AS: Anchieta sheltered rocky shore, AE: Anchieta exposed rocky shore, GS: Guarapari sheltered rocky shore and GE: Guarapari exposed rocky shore.

Table 3. Summary of results of three-way analysis of variance (ANOVA) on effects of the sampling location (Anchieta and Guarapari, southeastern Brazil), rocky shores (sheltered and exposed) and seasons (rainy and dry) in the abundance, richness, diversity, equitability and dominance indices of the decapod community. F: variance ratio, $P$ : significance.

\begin{tabular}{|c|c|c|c|c|c|c|c|c|c|c|}
\hline \multirow{2}{*}{ Sources of variation } & \multicolumn{2}{|c|}{ Abundance } & \multicolumn{2}{|c|}{ Richness } & \multicolumn{2}{|c|}{ Diversity } & \multicolumn{2}{|c|}{ Equitability } & \multicolumn{2}{|c|}{ Dominance } \\
\hline & $\mathrm{F}$ & $P$ & $\mathrm{~F}$ & $P$ & F & $P$ & $\mathrm{~F}$ & $P$ & $\mathrm{~F}$ & $P$ \\
\hline Regions & 8.637 & 0.005 & 2.506 & 0.121 & 6.091 & 0.018 & 1.276 & 0.265 & 0.117 & 0.734 \\
\hline Rocky shores & 0.071 & 0.792 & 22.55 & 0.000 & 11.566 & 0.002 & 2.521 & 0.120 & 0.068 & 0.795 \\
\hline Seasons & 0.021 & 0.885 & 0.011 & 0.916 & 0.184 & 0.671 & 0.02 & 0.889 & 0.808 & 0.374 \\
\hline 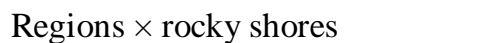 & 0.463 & 0.500 & 1.347 & 0.253 & 0.170 & 0.682 & 2.488 & 0.123 & 3.252 & 0.079 \\
\hline & 837 & 0.366 & 0.100 & 0.753 & 0.047 & 0.8 & 0.001 & 0.971 & 0.767 & 0.386 \\
\hline & & 0.446 & 0.011 & 0.9 & 1.107 & 0.299 & 0.161 & 0.691 & 0.003 & 0.959 \\
\hline Regions $\times$ rocky shores $\times$ seasons & 0.596 & 0.445 & 0.278 & 0.601 & 0.000 & 0.996 & 0.276 & 0.602 & 0.872 & 0.356 \\
\hline
\end{tabular}

ment, since it was found a greater diversity of gastropods shells in Guarapari (20 species) than in Anchieta (15 species) (C.C. Ribeiro, unpubl. data).
According to Ayres-Peres et al. (2008), the availability of gastropod shells may directly affect the biology of hermit crabs, and the shortage of these shells may hinder 

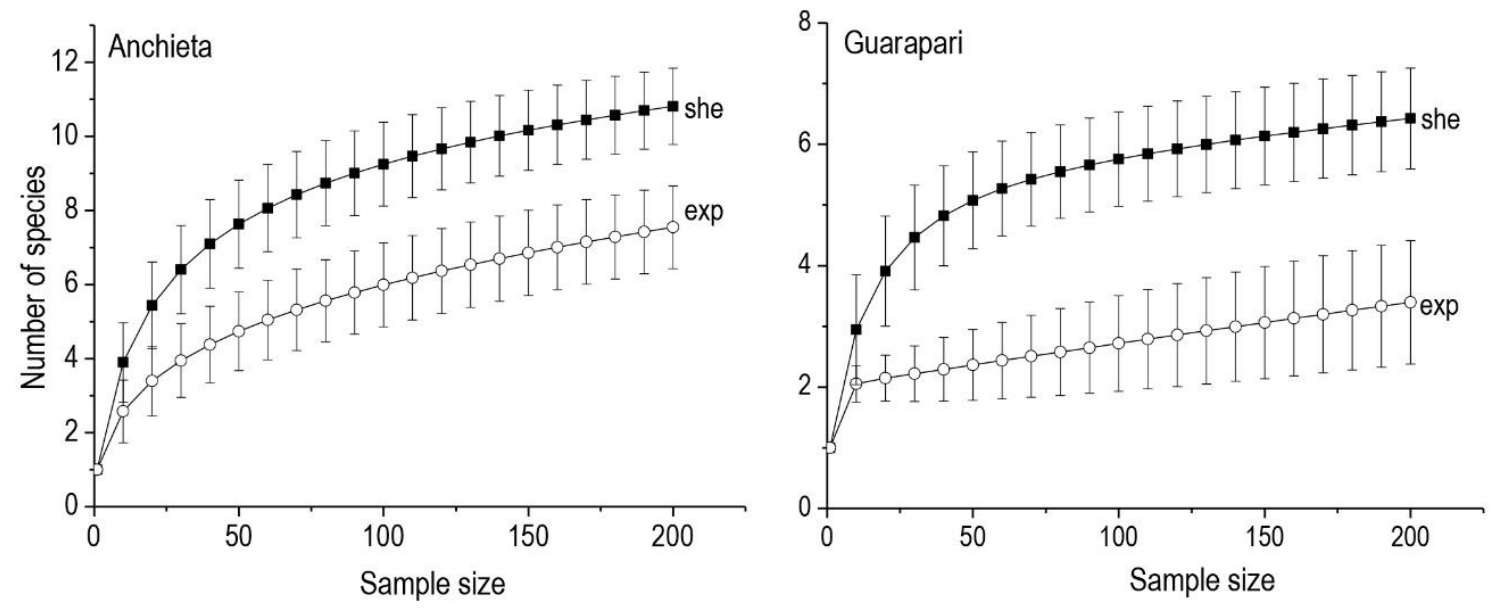

Figure 4. Rarefaction curves observed for decapod species in sheltered (she) and exposed (exp) rocky shores of Anchieta and Guarapari, southeastern Brazil.

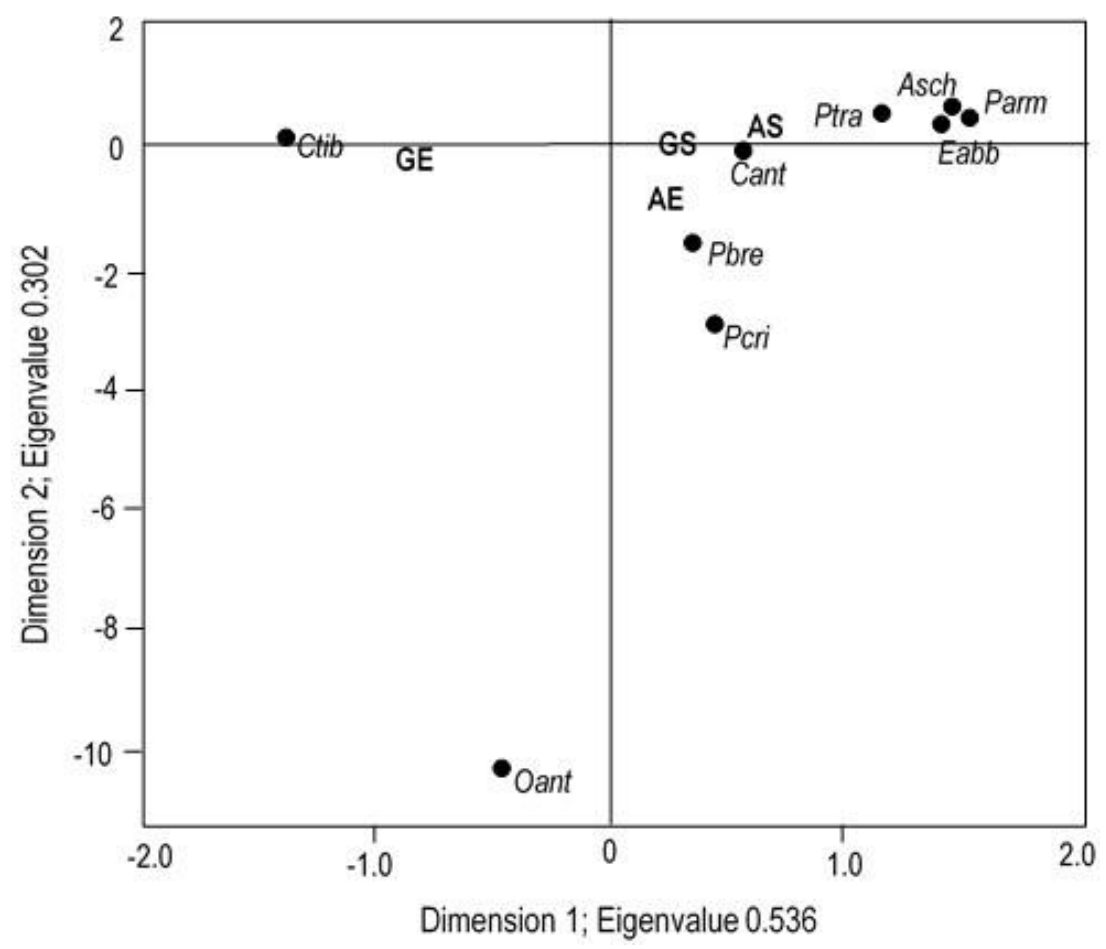

Figure 5. Correspondence analysis evaluating the spatial abundance of decapod species based on Bray-Curtis similarity matrices concerning rocky shores (sheltered and exposed) in Anchieta and Guapari. AS: Anchieta sheltered rocky shore, AE: Anchieta exposed rocky shore, GS: Guarapari sheltered rocky shore, GE: Guarapari exposed rocky shore, southeastern Brazil. Cti: Calcinus tibicen, Cant: Clibanarius antillensis, Parm: Petrolisthes armatus, Asch: Acantholobulus schmitti, Eabb: Eurypanopeus abbreviatus, Ptra: Pachygrapsus transversus, Pbre: Pagurus brevidactylus, Pcri: Pagurus criniticornis, Oant: Omalacantha antillensis.

the growth and reproduction of these anomurans. Thus, studies regarding these topics are essential for a better understanding of the habitat preference of decapods and their ecological role in a given environment.

Other species of hermit crabs such as Pagurus criniticornis and Pagurus brevidactylus were more abundant in Anchieta than in Guarapari. According to Almeida et al. (2010), these species can live in many habitats, like sand and mud bottoms, reefs, among rocks, algae and in fragments of shells and corals. Thus, the available resources at the rocky shores of Anchieta possibly allowed a high abundance of these species in this area. 
The group of species composed by Eurypanopeus abbreviatus, Acantholobulus schmitti, Pachygrapsus transversus and the porcelain crab Petrolisthes armatus showed a high correspondence to protected coasts at both localities (AS and GS), since they were present almost exclusively in these places, and their occurrence varied from common to constant. Their biology explains the occurrence of these species in sheltered environments: e.g., $P$. transversus lives in any mediolittoral zone offering shelter like cracks and holes to relieve thermal stress and dehydration during low tide (Abele et al., 1986; Agnew \& Taylor, 1986; Masunari \& Dubiaski-Silva, 1998). Similarly, other species such as E. abbreviatus and A. schmitti are protected in the spaces between rocks during low tide periods and are usually found buried in the substrate formed by mud, sand or gravel (Masunari \& DubiaskiSilva, 1998; Fransozo et al., 2013), whereas P. armatus occupies any hiding place, under stones, corals, sponges or bank of mussels (Veloso \& Melo, 1993).

The spider crab Omalacantha antillensis showed high correspondence with $\mathrm{AE}$, demonstrating a high frequency in this rocky shore, especially within tidal pools with large amounts of algae. The crabs of the genus Omalacantha and Acanthonyx are known for their herbivorous habit and for using algae for camouflage as a defensive strategy against predators (Stachowicz \& Hay, 2000; Blanco et al., 2011; Carvalho et al., 2016). Therefore, their occurrence in this area allows the use of algae for camouflage, besides contributing to their feeding.

The other species collected (Clibanarius sclopetarius, Paguristes tortugae, Epialtus bituberculatus, Eriphia gonagra, and Menippe nodifrons) were less frequent, varying from occasional to rare. This low abundance of these decapod species may be related to sampling difficulties as observed for $E$. gonagra and $M$. nodifrons, which occupy rock cracks during low tides (Masunari \& Dubiaski-Silva, 1998). Future studies with a collection effort directed to the more agile and cryptic brachyurans may help to provide more accurate information about the presence and abundance of these crabs in the region.

Regarding the rainy and dry seasons, no relationships were detected in the association of the decapod fauna and environmental factors, since the values of temperature, salinity and rainfall among the collection sites varied very little between seasons. Rainfall could be a preponderant factor for the presence of intertidal decapods, however, according to Ramos et al. (2016), the hydrological year of 2014-2015 was considered atypical in the state of ES, being drier than the historical average recorded in the state, with a rainfall deficit of up to $75 \%$, and classified as "extremely dry". Thus, despite the differences observed between rainy and dry seasons in the average volume of rainfall in the week before the collection, the amount of rainfall was low, showing no correlation with the decapods present in these environments.

The physical characteristics of the intertidal zone are the primary factors influencing the habitat partitioning by decapods (Masunari \& Dubiaski-Silva, 1998). Considering that, the present study was carried out in the mediolittoral zone and the environmental factors were homogeneous in the studied periods, it is assumed that the species distribution was possibly related to their biological characteristics and the physical differences of each type of rocky shore rather than to environmental factors. However, in studies that considered a more extensive range of intertidal areas, it was possible to detect seasonal differences: Masunari et al. (1998) in Ilha do Farol (Paraná) and Morais \& Lee (2014) in intertidal rare rocky fragments in the Brazilian Amazonian coast.

In conclusion, the information generated in this study is relevant to improving the knowledge about the fauna of anomurans and brachyurans of the rocky shores located in the State of Espírito Santo. This faunal study was carried out before the disruption of a mining dam in November 2015, which reached the coast of Espírito Santo and caused one of the biggest environmental catastrophes in Brazil. Therefore, these data can be used for future monitoring strategies, environmental conservation measures and the sustainable use of natural resources of the region.

\section{ACKNOWLEDGMENTS}

To Dr. Valter José Cobo for his contribution in the identification of some specimens of brachyurans and anomurans. To the Biocrust group for helping with the sampling and sorting of the animals. To Dr. Luis Carlos Ferreira de Almeida for his help with statistical analyses.

\section{REFERENCES}

Abele, L.G., Campanella, P.J. \& Salmon, M. 1986. Natural history and social organization of the semiterrestrial grapsid crab Pachygrapsus transversus (Gibbes). Journal of Experimental Marine Biology and Ecology, 104(1-3): 153-170.

Abushaala, N.M., Shaibi, T. \& Howaege, H.M. 2014. The abundance and diversity of benthic crustaceans along the coastal zone of Western Libya. Journal of the Black Sea / Mediterranean Environment, 20(1): 33-45.

Agnew, D.J. \& Taylor, A.C. 1986. Effects of oxygen tension, temperature, salinity, and humidity on the 
survival of two intertidal gammarid amphipods. Marine Ecology Progress Series, 32(1): 27-33.

Ahmad, O., Fang, T.P. \& Yahya, K. 2011. Distribution of intertidal organisms in the shores of Teluk Aling, Pulau Pinang, Malaysia. Publications of the Seto Marine Biological Laboratory, 41: 51-61.

Almeida, A.O., Souza, G.B.G., Boehs, G. \& Bezerra, L.E.A. 2010. Shallow-water anomuran and brachyuran crabs (Crustacea: Decapoda) from southern Bahia, Brazil. Latin American Journal of Aquatic Research, 38(3): 329-376.

Araújo, R., Bárbara, I., Sousa-Pinto, I. \& Quintino, V. 2005. Spatial variability of intertidal rocky shore assemblages in the northwest coast of Portugal. Estuarine, Coastal and Shelf Science, 64(4): 658-670.

Ayres-Peres, L., Sokolowicz, C.C., Kotzian, C.B., Rieger, P.J. \& Santos, S. 2008. Ocupação de conchas de gastrópodes por ermitões (Decapoda, Anomura) no litoral de Rio Grande, Rio Grande do Sul, Brasil. Iheringia, Serie Zoología, 98(2): 218-224.

Barbosa, S.O., Figueiredo, M.A.P. \& Testa, V. 2008. Estrutura e dinâmica de comunidades bentônicas dominadas por macrófitas na zona intramareal da Praia de Jacaraípe, Espírito Santo, Brasil. Hoehnea, 35(4): 563-575.

Barros-Alves, S.P., Alves, D.F.R. \& Cobo, V.J. 2017. Brachyuran crab (Crustacea, Decapoda) assemblage associated with Sargassum cymosum in southeastern Brazil. Marine Biodiversity, 48(4): 2043-2055. doi: 10.1007/s12526-017-0730-3

Berger, W.H \& Parker, F.L. 1970. Diversity of planktonic foraminifera in deep-sea sediments. Science, 168: 1345-1347.

Bertini, G., Fransozo, A. \& Melo, G.A.S. 2004. Biodiversity of brachyuran crabs (Crustacea: Decapoda) from non-consolidated sublittoral bottom on the northern coast of São Paulo State, Brazil. Biodiversity and Conservation, 13(12): 2185-2207.

Bertini, G., Fransozo, A. \& Negreiros-Fransozo, M.L. 2010. Brachyuran soft-bottom assemblage from marine shallow waters in the southeastern Brazilian littoral. Marine Biodiversity, 40(4): 277-291.

Bertness, M.D. 1981. Predation, physical stress and the organization of a tropical rocky intertidal hermit crab community. Ecology, 62: 411-425.

Blanco, C.G., Gusmão-Júnior, J.B.L., Christofoletti, R.A. \& Costa, T.M. 2011. Hydrodynamism and its influence on the density of the decorator crab Microphrys bicornutus (Mithracidae) on intertidal rocky shores from a subtropical region. Marine Biology Research, 7(7): 727-731.

Bruno, J.F. \& Bertness, M.D. 2001. Habitat modification and facilitation in benthic marine communities. In: Bertness, M.D., Gaines, S.D. \& Hay, M.E. (Eds.).
Marine community ecology. Sinauer Associates, Sunderland, pp. 201-218.

Carvalho, F.R.P., Rodrigues, R.O., Barreto, R.E. \& Costa, T.M. 2016. Decoration behaviour in a spider crab, Acanthonyx scutiformis (Dana, 1851) in relation to life stage, sex, and algal species. Crustaceana, 89(6-7): 775-786.

Colwell, R.K., Mao, C.X. \& Chang, J. 2004. Interpolating, extrapolating, and comparing incidence-based species accumulation curves. Ecology, 85: 2717-2727.

Coutinho, R., Vaginuma, L.E., Siviero, F., Santos, J.C.Q.P., López, M.S., Christofoletti, R.A., Berchez, F., Ghilardi-Lopes, N.P., Ferreira, C.E.L., Gonçalves, J.E.A., Masi, B.P., Correia, M.D., Sovierzoski, H.H., Skinner, L.F. \& Zalmon, I.R. 2016. Studies on benthic communities of rocky shores on the Brazilian coast and climate change monitoring: status of knowledge and challenges. Brazilian Journal of Oceanography, 64(2): 27-36.

Crowe, T.P., Thompson, R.C., Bray, S. \& Hawkins, S.J. 2000. Impacts of anthropogenic stress on rocky intertidal communities. Journal of Aquatic Ecosystem Stress and Recovery, 7(4): 273-297.

Cruz, C.V. 2014. Composição da fauna associada à Ulva spp. Delile (Ulvales, Ulvaceae) em três áreas do litoral do estado do Espírito Santo, Brasil. Revista Eletrônica de Biologia, 7(4): 387-417.

Dajoz, R. 2005. Princípios de ecologia. Artimed, Porto Alegre.

De Grave, S., Pentcheff, N.D., Ahyong, S.T., Chan, T.Y., Crandall, K.A., Dworschak, P.C., Felder, D.L., Feldmann, R.M., Fransen, C.H.J.M., Goulding, L.Y.D., Lemaitre, R., Low, M.E.Y., Martin, J.W., Ng, P.K.L., Schweitzer, C.E., Tan, S.H., Tshudy, D. \& Wetzer, R. 2009. A classification of living and fossil genera of decapod crustaceans. Raffles Bulletin of Zoology, 21: 1-109.

Floeter, S.R., Krohling, W., Gasparini, J.L., Ferreira, C.E.L. \& Zalmon, I.R. 2007. Reef fish community structure on coastal islands of the southeastern Brazil: the influence of exposure and benthic cover. Environmental Biology of Fishes, 78(2): 147-160.

Flores, A.A.V. \& Paula, J. 2001. Intertidal distribution and species composition of brachyuran crabs at two rocky shores in central Portugal. In: Paula, J.P.M., Flores, A.A.V. \& Fransen, C.H.J.M. (Eds.). Advances in decapod crustacean research. Kluwer Academic Publishers, Dordrecht, pp.171-177.

Fransozo, V., Silva, T.E., Fumis, P.B., Bertini, G. \& Lima, P.A. 2013. Ecological distribution and population structure of Acantholobulus schmitti (Rathbun, 1930) (Crustacea, Decapoda, Xanthoidea) on the southeastern brazilian coast. Brazilian Journal of Oceanography, 61(4): 277-287. 
Fransozo, A., Fernandes-Góes, L.C., Fransozo, V., Góes, J.M., Cobo, V.J., Teixeira, G.M. \& Gregati, R.A. 2011. Marine anomurans (Decapoda) from the nonconsolidated sublittoral bottom at the southeastern coast of Brazil. Crustaceana, 84(4): 435-450.

Gherardi, F. \& Vannini, M. 1993. Hermit crabs in a mangrove swamp: proximate and ultimate factors in the clustering of Clibanarius laevimanus. Journal of Experimental Marine Biology and Ecology, 168(2): 167-187.

Ghilardi, N.P., Filho, G.H.P. \& Berchez, F. 2008. Current knowledge status of the ecology of hard bottom benthic communities in Brazil and the need for new approaches. Oecologia Brasiliensis, 12(2): 197-205.

Giraldes, B.W., Coelho-Filho, P.A. \& Coelho, P.A. 2012. Composition and spatial distribution of subtidal Decapoda on the "Reef Coast," northeastern Brazil, evaluated through a low-impact visual census technique. Nauplius, 20(2): 187-201.

Gittins, R., 1985. Canonical analysis: a review with applications in ecology. Springer-Verlag, Berlin.

Gotelli, N.J. \& Colwell, R.K. 2010. Estimating species richness. In: Magurran, A.E. \& McGill, B.J. (Eds.). Biological diversity: frontiers in measurement and assessment. Oxford University, Oxford, pp. 39-54.

Kawasaki, H., Sano, M. \& Shibuno, T. 2003. The relationship between habitat physical complexity and recruitment of the coral reef damselfish, Pomacentrus amboinensis: an experimental study using small-scale artificial reefs. Ichthyological Research, 50: 73-77.

Krebs, C.J. 1998. Ecological methodology. Benjamin, New York.

Leite, F.P.P., Turra, A. \& Gandolfi, S.M. 1998. Hermit crabs (Crustacea: Decapoda: Anomura), gastropod shells and environmental structure: their relationship in southeastern Brazil. Journal of Natural History, 32(10-11): 1599-1608.

Leps, J. \& Smilauer, P. 2003. Multivariate analysis of ecological data using CANOCO. Cambridge University Press, Cambridge.

Macieira, R.M. \& Joyeux, J.C. 2011. Distribution patterns of tidepool fishes on a tropical flat reef. Fishery Bulletin, 109(3): 305-315.

Masunari, S. \& Dubiaski-Silva, J. 1998. Crustacea Decapoda da praia rochosa da Ilha do Farol, Matinhos, Paraná. II. Distribuição espacial de densidade das populações. Revista Brasileira de Zoologia, 15(3): 643-664.

Masunari, S., Oliveira, E. \& Kowalczuk, V.G.L. 1998. Crustacea Decapoda da praia rochosa da Ilha do Farol, Matinhos, Paraná. I. Distribuição temporal de densidade das populações. Revista Brasileira de Zoologia, 15(1): 219-239.
Melo, G.A.S. 1996. Manual de identificação dos Brachyura (caranguejos e siris) do litoral brasileiro. Plêiade, São Paulo.

Melo, G.A.S. 1999. Manual de identificação dos Crustacea Decapoda do litoral brasileiro: Anomura, Thalassinidea e Astacidea. Plêiade, São Paulo.

Morais, G.C. \& Lee, J.T. 2014. Intertidal benthic macrofauna of rare rocky fragments in the Amazon region. Revista de Biología Tropical, 62(1): 69-86.

Moreno, T.R. \& Rocha, R.M. 2012. Ecologia de costões rochosos. Estudos de Biologia: Ambiente e Diversidade, 34(83): 191-201.

Nalesso, R.C., Joyeux, J.C., Quintana, C.O., Torezani, E. \& Otegui, A.C.P. 2005. Soft-bottom macrobenthic communities of the Vitória Bay estuarine system, south-eastern Brazil. Brazilian Journal of Oceanography, 53(1-2): 23-38.

Nanami, A., Saito, H., Akita, T., Motomatsu, K. \& Kuwahara, H. 2005. Spatial distribution and assemblage structure of microbenthic invertebrates in a brackish lake in relation to environmental variables. Estuarine, Coastal and Shelf Science, 63(1-2): 167176.

Nóbrega, P.S.V. \& Martinelli-Lemos, J.M. 2016. Composition and spatiotemporal variation in the density of the Brachyura (Decapoda, Pleocyemata) in the rocky substrates of an Amazonian estuary. Crustaceana, 89(13): 1447-1466.

Nucci, P.R., Turra, A. \& Morgado, E.H. 2001. Diversity and distribution of crustaceans from 13 sheltered sandy beaches along São Sebastião Channel, southeastern Brazil. Journal of the Marine Biological Association of the United Kingdom, 81: 475-484.

Odum, E.P. \& Barrett, G.W. 2007. Fundamentos de ecologia. Thomson Pioneira, São Paulo.

Olawusi-Peters, O.O. \& Ajibare, A.O. 2014. Species richness, diversity, and abundance of some decapod crustaceans in coastal waters of Ondo State, South West, Nigeria. International Journal of Fauna and Biological Studies, 1(5): 44-51.

Osawa, M. \& Fujita, Y. 2008. Clibanarius ambonensis (Crustacea: Decapoda: Anomura: Diogenidae) from the Ryukyu Islands, south-western Japan. Marine Biodiversity Records, 1: 1-8.

Pielou, E.C. 1966. The measurement of diversity in different types of biological collections. Journal of Theoretical Biology, 13: 131-144.

Pohle, G., Iken, K., Clarke, K.R., Trott, T., Konar, B., Cruz-Motta, J.J., Wong, M., Benedetti-Cecchi, L., Mead, A., Miloslavich, P., Mieszkowska, N., Milne, R., Tamburello, L., Knowlton, A., Kimani, E. \& Shirayama, Y. 2011. Aspects of benthic decapod diversity and distribution from rocky nearshore habitat 
at geographically widely dispersed sites. Plos One, 6(4): e18606. doi: 10.1371/journal.pone.0018606

Ramos, R.J., Travassos, M.P. \& Leite, G.R. 2010. Characterization of macrofauna associated with articulated calcareous algae (Corallinaceae, Rhodophyta) occurring in a hydrodynamic gradient on the Espírito Santo state coast, Brazil. Brazilian Journal of Oceanography, 58(4): 275-285.

Ramos, H.E.A., Silva, B.F.P., Brito, T.T., Silva, J.G.F., Pantoja, P.H.B., Maia, I.F. \& Thomaz, L.B. 2016. A estiagem no ano hidrológico 2014-2015 no Espírito Santo. Incaper, 6-7(4): 6-25.

Schilling, A.C. \& Batista, J.L.F. 2008. Curva de acumulação de espécies e suficiência amostral em florestas tropicais. Revista Brasileira de Botânica, 31(1): 179-187.

Silva, C.C. \& Castro, G.A. 2014. Caecidae gastropods found in beds of the mussel Perna perna (Bivalvia: Mytilidae), on the rocky shores of Benevente Bay, Espírito Santo State. Arquivos de Ciências do Mar, 47(2): 80-85.

Stachowicz, J.J. \& Hay, M.E. 2000. Geographic variation in camouflage specialization by a decorator crab. The American Naturalist, 156(1): 59-71.

Széchy, M.T.M. \& Paula, E.J. 2000. Padrões estruturais quantitativos de bancos de Sargassum (Phaeophyta, Fucales) do litoral dos estados do Rio de Janeiro e São Paulo. Brasil. Revista Brasileira de Botânica, 23(2): 121-132.

Received: 8 May 2018; Accepted: 3 March 2019
Taylor, P.T. 1981. Hermit crab fitness: the effect of shell condition and behavioral adaptations on environmental resistance. Journal of Experimental Marine Biology and Ecology, 52(2-3): 205-218.

Thompson, R.C., Crowe, T.P. \& Hawkins, S.J. 2002. Rocky intertidal communities: past environmental changes, present status, and predictions for the next 25 years. Environmental Conservation, 29(2): 168-191.

Veloso, V.G. \& Melo, G.A.S. 1993. Taxonomia e distribuição da família Porcellanidae (Crustacea, Decapoda, Anomura) no litoral brasileiro. Iheringia, Série Zoologia, 75: 171-186.

Wilson, W.H. 1991. Competition and predation in marine soft-sediment communities. Annual Review of Ecology, Evolution, and Systematics, 21: 221-241.

Zalmon, I.R., Krohling, W. \& Ferreira, C.E.L. 2011. Abundance and diversity patterns of the sessile microbenthic community associated with environmental gradients in Vitória Harbor, southeastern Brazil. Zoologia, 28: 641-652.

Zamprogno, G.C., Fernandes, F.C. \& Fernandes, L.L. 2012. Temporal and spatial variation of rocky shores intertidal benthic communities in southeast Brazil. Iheringia, Série Zoologia, 102(4): 375-383.

Zar, J.H. 1999. Biostatistical analysis. Prentice-Hall, New Jersey. 